\title{
How Clear is "Clear"?: A Lenient Interpretation of the Gregory $v$ Ashcroft Clear Statement Rule
}

\author{
Michael P. Lee $\dagger$
}

\section{INTRODUCTION}

The clear statement rule is a method of statutory interpretation that courts apply when a federal statute alters the balance of power between the federal government and the states. ${ }^{1}$ In these situations, courts require legislators to draft statutory language that unmistakably states congressional intent to modify the federal-state balance. In the absence of a clear statement, courts will hold a statute inapplicable to the states. The clear statement rule was developed principally as a method for courts to ensure that Congress adequately deliberated before abrogating the states' Eleventh Amendment immunity from suit in federal court, and the rule has been applied subsequently in a number of other situations in which federalism interests are implicated. ${ }^{2}$

In Gregory $v$ Ashcroft, ${ }^{3}$ the Supreme Court extended the clear statement rule to congressional interference with "state de-

$\dagger$ B.S. 1983, University of Washington; M.S. 1984, Stanford University; Ph.D. 1991, Stanford University; J.D. Candidate 1998, The University of Chicago.

1 For a comprehensive overview of the clear statement principle, see William N. Eskridge, Jr. and Philip P. Frickey, Quasi-Constitutional Law: Clear Statement Rules as Constitutional Lawmaking, 45 Vand L Rev 593 (1992).

The clear statement rule also has been applied in other areas in which important rights or structural interests are implicated, for example, individual rights, violation of international treaties, and congressional derogation of presidential power to regulate foreign affairs. Id at 598-629 (describing areas where the Supreme Court has applied the clear statement rule). This Comment, however, focuses on the application of the rule in the federalism context, and specifically in the area of congressional interference in core state functions.

${ }^{2}$ See, for example, BFP $v$ Resolution Trust Corp, 511 US 531, 544-45 (1994) (federal preemption of pre-existing state law); Gregory $v$ Ashcroft, 501 US 452, 461 (1991), citing Sugarman v Dougall, 413 US 643, 647 (1973) (federal interference with "state decisions that go to the heart of representative government"); Atascadero State Hospital $v$ Scanlon, 473 US 234, 242 (1984) (federal abrogation of the states' Eleventh Amendment immunity to suit in federal court). See also Eskridge and Frickey, 45 Vand L Rev at 621 (cited in note 1) (suggesting a strong rule against congressional waiver of states' Eleventh Amendment immunity from suit in federal court); Calvin R. Massey, Etiquette Tips: Some Implications of "Process Federalism", 18 Harv J L \& Pub Pol 175, 192 (1994) (giving a brief history of the clear statement rule).

3501 US 452, 452-53 (1991) (finding that the Age Discrimination in Employment Act did not clearly state that it would apply to state court judges). See also Eskridge and 
cisions that 'go to the heart of representative government."' The general outline of the Gregory rule can be stated simply: if Congress wishes to regulate a core state function, it must make its intent "unmistakably clear" in the statutory text. ${ }^{5}$

Uncertainty over the precise nature of the Gregory test has led federal courts to disagree over the applicability of important federal legislation to the states. ${ }^{6}$ Two aspects of the Gregory clear statement rule are unclear. First, what operations are included in the category of core state functions? ${ }^{7}$ Second, what statutory language will suffice as a "clear statement"? Can Congress use broad statutory language to state clearly its intent to regulate a particular state function, or must it explicitly enumerate the state operations covered by the statute? ${ }^{8}$ This Comment focuses on the second area of uncertainty.

Frickey, 45 Vand L Rev at 623 (cited in note 1).
401 US at 461 , quoting Sugarman, 413 US at 647 .
s See Gregory, 501 US at $460-61$, quoting Atascadero, 473 US at 242 ("[I]f Congress
intends to alter the 'usual constitutional balance between the States and the Federal
Government,' it must make its intention to do so 'unmistakably clear in the language of
the statute.").

${ }^{6}$ For example, federal appellate courts disagree about whether the public services provision of the Americans with Disabilities Act ("ADA") applies to persons incarcerated in state prisons. Compare Torcasio v Murray, 57 F3d 1340, 1345 (4th Cir 1995), cert denied as Torcasio $v$ Angelone, $116 \mathrm{~S}$ Ct 772 (1996) (finding that the ADA did not clearly apply to obese state prison inmate), with Yeskey $v$ Pennsylvania Department of Corrections, 118 F3d 168, 174 (3d Cir 1997) (holding that the ADA protected a state prison inmate with a history of hypertension). This issue is discussed in detail in Part II.

7 After the Court's discussion in Gregory, this category might be confined to those functions that lie at "the heart of representative government," such as the power to specify the qualifications of government officials. See Gregory, 501 US at 461, quoting Sugarman, $413 \mathrm{US}$ at 647. However, given the open-ended language in the Gregory decision, courts and commentators have suggested that this term also can be construed more broadly to include any operation that is arguably in the province of the states. See Gregory, 501 US at 478 (White concurring) (stating that the majority decision in Gregory failed to explain whether clear statement review is limited to federal regulation of the qualifications of state officials or whether it applied more broadly to the regulation of all state governmental functions). See also Bruce Dayton Livingston, Gregory v. Ashcroft: The Supreme Court Announces a New Rule of Statutory Construction in Deference to Constitutionally Recognized Principles of Federalism, 11 SLU Pub L Rev 243, 244 (1992) (noting that Gregory can be construed narrowly, to apply only to the qualifications of important state officers, or broadly, to apply to any statute that might conceivably intrude upon "state governmental functions"); Deanna L. Ruddock, Note, Gregory v. Ashcroft: The Plain Statement Rule and Judicial Supervision of Federal-State Relations, 70 NC L Rev 1563,1590 (1992) (noting that the Court in Gregory failed to place precise limits on the application of the clear statement rule). But see Laura $\mathrm{E}$. Walvoord, Comment, A Critique of Torcasio v. Murray and the Use of the Clear Statement Rule to Interpret the Americans with Disabilities Act, 80 Minn L Rev 1183, 1214 (1996) (stating that courts apply the clear statement rule only to state functions at "the heart of representative government") (citations omitted).

s When used in this Comment to describe statutory language, the terms "broad," "broadly applicable," and "generally applicable" mean language that encompasses the states and all of the states' functions. In contrast, "narrow" statutory language seeks to 
A clear statement rule requiring specific enumeration provides greater protection for state sovereignty. Under this version of the rule, Congress is obliged to carefully determine the specific state functions it wishes to regulate, because courts will limit the statute's coverage to the functions Congress explicitly lists in the statutory text. Many commentators and courts have suggested that the Gregory Court's application of the clear statement rule announced a requirement for enumeration. ${ }^{9}$ However, the Gregory Court confused the issue by stating that specific enumeration was not required. ${ }^{10}$

A lenient approach to clear statement review-one that finds a clear statement in clearly worded generally applicable statutory language-is more appropriate in the core state function context. The stricter specific enumeration approach is impractical insofar as it requires Congress to list every core state function it wishes to regulate, especially when a statute is intended to have broad applicability. ${ }^{11}$ Enumeration increases both legisla-

specify a subset of state functions covered by the statute, or to exclude state functions from coverage entirely.

- See Gregory, 501 US at 478 (White concurring) ("The vagueness of the majority's rule undoubtedly will lead States to assert that various federal statutes no longer apply to a wide variety of state activities if Congress has not expressly referred to those activities in the statute. Congress, in turn, will be forced to draft long and detailed lists of which particular state functions it meant to regulate."). See also Livingston, 11 SLU Pub $L$ Rev at 245 (cited in note 7) (noting that the Gregory clear statement rule "requires explicit mention of the particular results" to be achieved by the statute); Ruddock, Note, 70 NC L Rev at 1590 (cited in note 7) ("In Gregory, the Court forced Congress to specify with clarity the precise application of statutes within the statutes themselves."). Some courts have interpreted the Gregory clear statement rule to require enumeration before applying the ADA to disabled prisoners' claims. See, for example, Torcasio, 57 F3d at 1346. This issue is discussed in detail in Part II.

${ }^{10}$ See 501 US at 467.

"Many courts have recognized implicitly that requiring specific enumeration places a significant burden on Congress, and have attempted to alleviate that burden by moderating the tests they apply to statutory language. See id (stating that the Age Discrimination in Employment Act does not need to mention judges explicitly). See also Dellmuth $v$ Muth, 491 US 223, 233 (1989) (Scalia concurring) (suggesting that Congress may abrogate state sovereign immunity without explicit reference to that immunity or to the Eleventh Amendment); Yeskey, 118 F3d at 173 (stating that Torcasio's statement that Congress must specifically identify state or local prisons in the statutory text, if it wishes to regulate them, was expressly disavowed by the Supreme Court in Gregory); Mills $v$ Maine, 118 F3d 37, 42 (1st Cir 1997) (holding that the Fair Labor Standards Act contains the necessary clear statement of congressional intent to abrogate state sovereign immunity); Davidson $v$ Board of Governors of State Colleges and Universities for Western Illinois University, 920 F2d 441, 443 (7th Cir 1990) (In the Eleventh Amendment context, Judge Posner notes that abrogation of the states' sovereign immunity "in so many words ... [is a] degree of explicitness [that] is not required.") (citations omitted). But see William N. Eskridge, Jr. and Philip P. Frickey, Cases and Materials on Legislation: Statutes and the Creation of Public Policy 704 (West $2 \mathrm{~d}$ ed 1995) (suggesting that "magic words" or some other very specific statutory language is necessary to abrogate the states' Eleventh Amendment immunity) (citations omitted). 
tive decision costs, because it is costly for Congress to list the entire range of functions it intends to regulate, and error costs, because Congress may err by neglecting to include a function it intended to affect. In addition, while the clear statement rule is intended to increase decision costs by forcing congressional deliberation, these costs may lead to legislative paralysis. If Congress knows that it must enumerate every state function it wishes to regulate, it may be deterred from initiating important legislative efforts.

Thus, while the federalism interests protected by the Gregory clear statement rule are certainly important, these interests must be weighed against the harm that an overly stringent rule may cause. The lenient approach to the Gregory clear statement rule provides sufficient protection for state sovereignty while providing Congress the power to utilize its limited resources efficiently.

This Comment revisits Gregory to determine whether the lenient approach to clear statement analysis is an accurate interpretation of the Court's holding. It then determines that the Gregory rule does not require Congress to enumerate the state functions it wishes to regulate, but rather allows a flexible approach to statutory construction. Part I presents an overview of the clear statement rule and examines the Supreme Court's decision in Gregory, where the Court applied the clear statement principle in the context of core state functions. Part I also discusses the influence that the Gregory rule will have on the future drafting of statutes. Part II uses the lenient interpretation of the Gregory rule to analyze whether the public services provision of the Americans with Disabilities Act ("ADA") applies to disabled inmates in state correctional facilities, and concludes that the provision constitutes a clear statement that it covers these persons.

\section{GREGORY REVISITED: THE CLEAR STATEMENT RULE}

The Supreme Court has recently begun relying upon clear statement review as a tool for promoting federalism. ${ }^{12}$ The clear

${ }^{12}$ See, for example, Atascadero, 473 US at 241 (holding that a provision of the California Constitution that generally allowed suits to be brought against the state was not specific enough to abrogate the state's Eleventh Amendment immunity from suit in federal court); Pennhurst State School and Hospital v Halderman, 465 US 89, 117 (1984) (holding that a federal court that ordered state officials to conform to state law contravened the Eleventh Amendment); Gregory, 452 US at 460-61. See generally Eskridge and Frickey, 45 Vand L Rev at 593, 619-29 (cited in note 1); William N. Eskridge, Jr., Public Values in Statutory Interpretation, 137 U Pa L Rev 1007, 1028-32 (1989). Clear statement 
statement rule is essentially a default rule: courts will refrain from interpreting federal statutes to infringe upon state sovereignty, absent an unambiguously clear statement of congressional intent. Beginning with its decisions in Pennhurst State School and Hospital $v$ Halderman ${ }^{13}$ and Atascadero State Hospital $v$ Scanlon, ${ }^{14}$ the Court has enforced this principle in the Eleventh Amendment context with increasing vigor. ${ }^{15}$ This development is part of a trend in which the Court is moving from direct invalidation of statutes to requiring statutory language to meet constitutionally based tests. ${ }^{16}$

\section{A. The Clear Statement Rule in the Core State Function Context}

In Gregory, the Court translated the clear statement principle from the Eleventh Amendment context into the area of congressional regulation of core state functions. ${ }^{17}$ Gregory came in the wake of the Court's decision in Garcia $v$ San Antonio Metro Transit Authority, ${ }^{18}$ which eliminated the Tenth Amendment as a viable defense for the states against federal intervention. The Gregory Court rationalized the application of the clear statement rule to the core state function context by noting that "inasmuch as [the] Court in Garcia has left primarily to the political process the protection of the States against intrusive exercises of Con-

rules attempt to ensure that Congress deliberates before upsetting the federalist balance of power between the federal government and the states.

${ }^{23} 465$ US 89 (1984).

" 473 US 234 (1985).

${ }^{15}$ The Court now requires an unambiguous statement of congressional intent before it will permit Congress to abrogate the states' Eleventh Amendment immunity from suit in federal court. Hoffman $v$ Connecticut Department of Income Maintenance, 492 US 96, 101 (1989) (stating that Congress must make its intention to abrogate states' Eleventh Amendment immunity "unmistakably clear in the language of the statute"); Will v Michigan Department of State Police, 491 US 58, 65 (1989) (same); Atascadero, 473 US at 242 (same). See also Eskridge and Frickey, 45 Vand $L$ Rev at 621 (cited in note 1). Eskridge and Frickey term this development a "steroidal transformation" of the clear statement review from a rule that was "alive and well but lacking Herculean power" into what is now a "super-strong" principle of statutory interpretation. Id. The clear statement rule is a super-strong rule because it "establish[es] very strong presumptions of statutory meaning that can be rebutted only through unambiguous statutory text targeted at the specific problem." Id at 611-12.

${ }^{16}$ See Eskridge and Frickey, 45 Vand L Rev at 597 (cited in note 1) (terming this a change from "constitutional law" to "quasi-constitutional law"). These tests are called quasi-constitutional because Congress may overcome them by drafting appropriate statutory language. Id.

${ }^{17}$ See 501 US at 460-61.

${ }^{18} 469$ US 528, 550-54 (1985) (noting that state and local governments must look to the political process for protection against intrusive federal statutes), overruling National League of Cities $v$ Usery, 426 US 833 (1976). 
gress' Commerce Clause powers, we must be absolutely certain that Congress intended such an exercise. ${ }^{\prime 19}$

Despite the importance of the federalism interests protected by the Gregory rule, courts have applied the rule inconsistently, at times requiring enumeration and at other times finding a clear statement in nonspecific statutory language. This inconsistency relates to the competing concerns that arise when courts analyze the degree of enumeration required to overcome clear statement review. On the one hand, statutory language explicitly mandating coverage of a specific state function is the clearest possible indication of congressional intent, and therefore provides the greatest protection for state sovereignty.

On the other hand, requiring enumeration in broadly applicable statutes significantly increases decision and error costs, which has several negative consequences. First, Congress must expend scarce legislative resources to include all relevant core state functions in the statute. This problem is exacerbated by the Gregory Court's failure to define clearly the category of core state functions. ${ }^{20}$ The lack of precise information about the range of core state functions will force Congress-out of caution-to enumerate every state function it wishes to regulate.

Second, the high cost of drafting enumerated statutes may result in legislative paralysis. Congress will be deterred from initiating important legislative efforts, because of the impracticability of compiling exhaustive lists of state functions.

Third, Congress may mistakenly neglect to include a state function that it would have wanted to incorporate in the statute. Courts will then decline to effectuate the unintentionally omitted provision using the canon expressio unius est exclusio alterius. ${ }^{21}$

${ }^{19} 501$ US at 464 . The Court also noted that "to give the state-displacing weight of federal law to mere congressional ambiguity would evade the very procedure for lawmaking on which Garcia relied to protect states' interests." Id, quoting Laurence H. Tribe, American Constitutional Law $\S 6-25$ at 480 (Foundation 2d ed 1988). The Gregory holding avoids conflict with Garcia by permitting Congress to enact statutes that infringe upon any and all state functions, as long as Congress clearly states its intention to do so.

Note that, in addition to the Gregory clear statement rule, two other doctrines act to constrain federal interference with core state functions. First, Congress may not commandeer state governments by forcing them to implement federal regulatory programs. See Printz $v$ United States, 117 S Ct 2365, 2383 (1997), citing New York v United States, 505 US 144, 188 (1992). Second, the "absurd result" doctrine places an additional restraint on federal action. For a recent discussion of the interaction between this doctrine and the Gregory clear statement rule, see Crawford $v$ Indiana Department of Corrections, 115 F3d 481, 485-86 (7th Cir 1997).

${ }^{20}$ See note 7.

${ }^{21}$ The expression of one thing is the exclusion of another. 
Fourth, an enumerated statute is inherently inflexible, making it difficult for administrators and courts to adapt to changing circumstances. Congress will thus be forced to bear the cost of repeatedly amending the statute, or risk enacting a statute that quickly becomes outdated.

In summary, while the Gregory clear statement rule is intended to protect federalism interests, the disadvantages of a strict rule may make it appropriate for the courts to interpret broad statutory language to constitute a clear statement of congressional intent to abrogate state sovereignty.

If courts use the strict Gregory rule to narrow a statute's coverage in a manner that Congress did not intend, Congress always can rectify this problem by amending the statute. ${ }^{22}$ However, this remedy is imperfect for several reasons. First, Congress may fail to amend the statute, particularly if those adversely affected by a narrow construction of the statute are poorly organized or disenfranchised. ${ }^{23}$ Second, even if Congress does act, the process of invalidation and subsequent congressional amendment wastes both judicial and legislative resources. Third, those persons whose claims are rejected prior to the congressional override of the judicial decision may be irreparably harmed. For these reasons, congressional amendment is a poor remedy.

A careful reading of the Gregory decision indicates that unenumerated statutory language suffices to overcome clear statement review if two conditions are met: (1) the plain meaning of that language includes the core state function being affected; and (2) no exception to the statute's coverage can conceivably be read to create ambiguity regarding whether that core function is included. This approach is appropriate from a normative standpoint because its balancing of federalism interests and legislative costs is superior to the solitary emphasis on federalism interests inherent in a stricter clear statement rule. Moreover, this lenient reading of the Gregory clear statement rule is consistent with the

${ }^{22}$ See William N. Eskridge, Jr., Overriding Supreme Court Statutory Interpretation Decisions, 101 Yale L J 331 (1991) (surveying all congressional overrides of the Supreme Court's statutory interpretation decisions from 1967 to 1990).

${ }^{23}$ See id at 351-53. Eskridge notes that the likelihood of a congressional override is highly dependent on the identity of those adversely affected by the Court's decision. For instance, Eskridge predicts that decisions adversely affecting the federal government are highly likely to be overridden. Women's groups, the disabled, state and local governments, environmental groups, and organized workers also have been able to get Congress's attention. See id at 351-52. Groups that Eskridge identifies as less likely to achieve an override include consumers, litigants, nonbusiness and less wealthy taxpayers, and the poor. See id at 352. 
clear statement rule developed by the Court in the Eleventh Amendment context, ${ }^{24}$ the latter rule also can be construed to weigh federalism interests against legislative costs.

\section{B. A Close Reading of Gregory $v$ Ashcroft: Support for the Lenient View}

In Gregory, a group of Missouri state judges sued under the Age Discrimination in Employment Act ("ADEA") to block efforts by the state to force them to retire at the age of seventy under the mandatory retirement provision of the Missouri State Constitution. ${ }^{25}$ The plaintiffs cited language in the ADEA making it unlawful for an "employer" to discharge "any individual" because of that person's age, where "employer" is defined to include "a State or political subdivision of a State. ${ }^{.26}$ An amendment to the ADEA specifying exceptions to the statute's coverage provides that "employee" shall not include elected government officials, other high-ranking officials, or "appointees on the policymaking level...27

The Gregory Court proceeded through three steps in its analysis. First, the Court determined that the clear statement principle was applicable to the case because enforcing the ADEA in this situation would constitute federal regulation of a core state function. ${ }^{28}$ Second, the Court described the scope of the clear statement rule in the core state function context. ${ }^{29}$ Finally, the Court applied the rule to the language of the ADEA and held that the statute did not clearly state that it applied to'state court judges. ${ }^{30}$

In invoking the clear statement rule, the Court drew a parallel between the Eleventh Amendment and congressional interference in the fundamental operations of the states by noting

${ }^{24}$ See notes 11,15 , and accompanying text.

${ }^{25}$ See 501 US at 455-56, citing 29 USC $\$ \S 621-34$ (1994).

${ }^{2} 501$ US at 456, citing 29 USC $\$ \S 623(a), 631(a), 630(b)(2)$.

${ }^{27} 501$ US at 464-65, citing 29 USC $\$ 630(\mathrm{~b})$. In its entirety, this Section of the ADEA reads:

The term "employee" means an individual employed by any employer except that the term "employee" shall not include any person elected to public office in any State or political subdivision of any State by the qualified voters thereof, or any person chosen by such officer to be on such officer's personal staff, or an appointee on the policymaking level or an immediate adviser with respect to the exercise of the constitutional or legal powers of the office.

2s 501 US at 460 .

$\approx$ Id at $460-61$.

${ }^{30} \mathrm{Id}$ at 467. 
that federalism interests are implicated in both situations. ${ }^{31}$ Thus, to protect these interests, the Court required Congress to make a clear statement of its intent to alter the balance of power between the federal government and the states. ${ }^{32}$ The Court justified its application of the clear statement rule in Gregory by noting that the power to specify the qualifications of governmental officials such as state court judges was a state decision going "to the heart of representative government." ${ }^{.33}$ The Court, however, left open the question of whether the clear statement rule would be applicable to state functions beyond this narrow category. ${ }^{34}$

After invoking the clear statement rule, the Court described the nature of this test. ${ }^{35}$ Drawing analogies to its Eleventh Amendment jurisprudence, the Court stated that Congress must make its intent "unmistakably clear in the language of the statute. ${ }^{\text {n36 }}$ The Court thus adopted the rule that a clear statement may be sought only in the statute's text and not in other traditional tools of statutory construction, such as legislative history. ${ }^{37}$

However, the Gregory Court implicitly rejected the idea that the clear statement rule required specific enumeration of the offices covered by the ADEA. ${ }^{38}$ Instead, the Court provided a rather vague standard for interpreting statutory language: to constitute a clear statement, the statute need not explicitly refer to judges, but rather "it must be plain to anyone reading the Act that it covers judges. ${ }^{\text {"39 }}$ The Court did not provide a description of what

${ }^{31}$ See id at 460-61.

32 Id.

${ }^{33}$ Id at 463.

it This open-ended definition of the state functions protected by the clear statement rule has led to uncertainty about the scope of the rule. See note 7 and accompanying text.

${ }^{35}$ See 501 US at 461-64.

${ }^{36}$ Id at 460-61, quoting Atascadero, 473 US at 242.

${ }^{37}$ See 501 US at 460-61. In Dellmuth, the Court reaffirmed that in an Eleventh Amendment context it will look only at the text of a statute when applying clear statement analysis. 491 US at 230. As the Court stated:

[E]vidence of congressional intent must be both unequivocal and textual. . . . Legislative history generally will be irrelevant to a judicial inquiry into whether Congress intended to abrogate the Eleventh Amendment. If Congress' intention is "unmistakably clear in the language of the statute," recourse to legislative history will be unnecessary; if Congress' intention is not unmistakably clear, recourse to legislative history will be futile, because by definition the rule of Atascadero will not be met.

Id. Thus, Congress may not overcome clear statement review by drafting vague or ambiguous statutes and then stating its intention to abrogate state sovereignty in the legislative history. Note also that courts may not examine the regulations enforcing statutes in applying the clear statement test. See notes 116-18 and accompanying text.

${ }^{3}$ See 501 US at 467.

${ }^{9} \mathrm{Id}$. 
language short of enumeration would suffice as a clear statement. ${ }^{40}$ Nevertheless, the Court's application of the clear statement rule in Gregory provides insight into that question.

In applying the clear statement rule to the language of the $\mathrm{ADEA}$, the Court first examined the commonly understood meaning of the relevant statutory terms. ${ }^{41}$ The Court noted that, but for the amendment creating an exception for state officials, the ADEA would be interpreted to apply to state judges. As the Court stated, "[t]he ADEA plainly covers all state employees except those excluded by one of the exceptions. Where it is unambiguous that an employee does not fall within one of the exceptions, the Act states plainly and unequivocally that the employee is included. ${ }^{142}$ In so finding, the Court examined the plain meaning of the statutory terms, and did not interpret the statute's coverage more narrowly in light of the federalism interests implicated by the statute.

The Court, however, also found that the amendment excepting "appointees on the policymaking level" from the ADEA's coverage could conceivably be read to include state judges, and thus the exception created an ambiguity as to whether the ADEA covered these persons. ${ }^{43}$ The Court noted that this was an awkward reading of the phrase "appointees on the policymaking level," but stated that it was sufficient to create uncertainty as to the statute's coverage. ${ }^{44}$ The Court emphasized that because Congress is presumed not to interfere with core state functions, the burden is on Congress to overcome this presumption with its statutory language. ${ }^{45}$ In light of the ambiguity created by the phrase "appointees at the policymaking level," the Court held that the ADEA did not include a sufficiently clear statement of congressional intent to extend statutory protection to state judges. ${ }^{46}$

${ }^{40}$ See note 9 and accompanying text.

${ }^{41}$ See 501 US at 466-67.

42 Id at 467 (emphasis added).

${ }^{43}$ See id ("It is at least ambiguous whether a state judge is an 'appointee on the policymaking level." ).

"See id ("' A]ppointee at the policymaking level,' particularly in the context of the other exceptions that surround it, is an odd way for Congress to exclude judges; a plain statement that judges are not 'employees' would seem the most efficient phrasing.").

"s See id (" $[\Pi n$ this case we are not looking for a plain statement that judges are excluded. We will not read the ADEA to cover state judges unless Congress has made it clear that judges are included.").

${ }^{26}$ See id ("In the context of a statute that plainly excludes most important state public officials, 'appointee on the policymaking level' is sufficiently broad that we cannot conclude that the statute plainly covers appointed state judges. Therefore, it does not.”). 
The structure of the Gregory decision illuminates the Court's conception of clear statement review. The Court first examined the broad statutory language of the ADEA and found a clear statement; the Act explicitly stated that the term "employers" included the states; therefore, Congress had stated clearly its intent to extend statutory coverage to all state employees (including judges). ${ }^{47}$ The Court then examined the amendment creating exceptions to the ADEA's coverage and concluded that this amendment created uncertainty about the statute's applicability to the plaintiffs, thus precluding the finding of a clear statement. ${ }^{48}$ It is apparent that, in the absence of the ambiguitycreating amendment, the Court would have found the ADEA applicable to the core state function of employment of state court judges.

\section{A Two-Part Clear Statement Test in the Core State Function Context}

This analysis of the Gregory decision indicates that, in applying the clear statement rule in the core state function context, the Court focused on the clarity of the statutory language, rather than the breadth of the statute's reach. Under the plain meaning analysis adopted by the. Court, a generally applicable but clearly worded statute will satisfy the Gregory rule more easily than a more specifically applicable but vaguely worded statute.

This analysis of Gregory suggests a two-part test for clear statement review: (1) a statute will suffice as a clear statement if the plain meaning of the language logically encompasses the state function at issue; (2) however, if an exception to the statute's coverage arguably encompasses the same state function then the statute will not constitute a clear statement.

Under the first part of the test, if Congress intends to regulate a core state function, it need not draft specifically enumerated statutes as long as the plain meaning of the statute clearly encompasses the state function at issue. For example, a statement that a statute covers "all operations" of the "states and all of the states' divisions, agencies and instrumentalities" would plainly reach all state functions, and therefore would permit federal interference in these functions. This interpretation of the clear statement rule is consistent with the Gregory Court's holding that a statute need not be specifically enumerated to over-

${ }^{47}$ See id at 464, citing 29 USC $\S 630(\mathrm{~b})(2)$. See also 501 US at 466-67.

45 See 501 US at 467. 
come clear statement review. ${ }^{49}$ Moreover, under this version of the Gregory clear statement rule, the statutory text is confined to its plain meaning.

In some cases, it may not be evident whether the plain meaning of a statutory term clearly includes the state function at issue. In such cases, courts normally look to extratextual sources, such as legislative history and regulations, to construe statutes. ${ }^{50}$ However, because the Gregory clear statement rule limits courts to the four corners of the statutory text, this approach is foreclosed. ${ }^{51}$ Instead, in light of the federalism interests protected by the clear statement rule, if the plain meaning of the statute does not clearly include the function at issue, the statute should be interpreted narrowly.

Under the second part of the Gregory rule, exceptions to a statute's coverage are examined to determine whether they conceivably include the affected state function. If the Court finds that an exception is ambiguous, this will preclude the finding of a clear statement. Courts need not find that Congress probably intended to exclude the state function from coverage; instead, courts will presume that an exception includes a claimant, unless it is unambiguously clear that it does not.

Note, however, that statutory exceptions that are clearly drawn will be confined to their express limits. It will be impermissible for courts either to read these exceptions in an irrationally broad manner or to infer additional exceptions into the statute.

A reading of Gregory that applies plain meaning analysis to a statute's description of its coverage has several advantages over a clear statement rule requiring specific enumeration. First, legislative decision costs are reduced, because Congress does not need to compile a comprehensive list of the state functions it wishes to affect. Second, this decreased cost reduces the risk of legislative paralysis. Third, because statutes containing broad clearly worded statutory language may satisfy the Gregory rule, Congress can reduce the risk that it will mistakenly neglect to include a state function it wishes to affect. Finally, generally worded statutes are more amenable to adaptation in changing circumstances.

This reading of Gregory is a more lenient interpretation of the clear statement rule than that suggested by some courts and

See notes 9-11 and accompanying text. 11).

${ }^{50}$ See Eskridge and Frickey, Cases and Materials on Legislation ch 8 (cited in note

${ }^{31}$ See note 37 and accompanying text. 
commentators; therefore, a greater number of statutes will satisfy this clear statement test than if specific enumeration were required. ${ }^{52}$ This may raise concerns about whether the Gregory rule actually serves its purpose of guaranteeing that Congress has deliberated before electing to abrogate state sovereignty.

This argument can be rebutted by noting that the goal of the Gregory clear statement rule is to force congressional deliberation. The strict Gregory rule achieves this goal by requiring Congress to enumerate explicitly the core state functions it wishes to affect. While the lenient rule does not provide the same degree of protection for federalism interests, it does force some deliberation by applying a plain meaning construction to statutory language. This rule requires Congress to draft statutes with precision, and to define with clarity the range of functions it intends to affect. If Congress drafts a generally worded statement of statutory coverage that logically includes a state function, such as "a state or political subdivision of a State" (the phrase used in the ADEA), it can expect that courts will interpret the statute to mean what it says.

If, however, the plain meaning of the statute's language describing its coverage does not include the core state function at issue, the statute will be held inapplicable to that function. Congress cannot draft ambiguous language and then rely upon legislative history or other extratextual sources to make apparent its intent to affect state functions. Instead, Congress is forced to manifest this intention in the statutory text; otherwise, courts will apply the Gregory rule to prevent federal interference in core state functions.

In summary, while the lenient Gregory clear statement rule does not protect federalism interests as completely as the strict rule, the protection that it does provide is significant. In addition, this protection is achieved at a much lower cost than the strict rule.

Finally, the Gregory clear statement rule does not operate in a vacuum; to abrogate state sovereignty, statutes also must overcome a variety of other tests. If Congress wishes to subject the states to suit in federal court for alleged violation of a federal statute, in addition to satisfying the Gregory rule, it also must clearly state that the statute overrides the states' Eleventh

${ }^{52}$ See note 9 and accompanying text. 
Amendment immunity, ${ }^{53}$ and it must enact the statute pursuant to its authority under the Fourteenth Amendment. ${ }^{54}$

The Gregory clear statement rule works in concert with these other rules to provide protection for federalism. In satisfying the Eleventh Amendment and Fourteenth Amendment tests, Congress unambiguously states its intent to abrogate state sovereignty. The Gregory rule then ensures that Congress sought to affect the particular state function at issue. If Congress satisfies the Eleventh and Fourteenth Amendment tests, and then elects to describe a statute's coverage in clearly worded generally applicable terms, courts should conclude that Congress has stated clearly its intent to interfere with core state functions.

Although the rules developed for the Eleventh Amendment and Fourteenth Amendment contexts are often applied strictly, ${ }^{55}$ the lenient clear statement rule from Gregory is consistent with these rules. Congress generally can satisfy the Eleventh and Fourteenth Amendment rules with single sentences. ${ }^{56}$ Thus, the costs incurred in satisfying these rules are minimal, and it is appropriate to emphasize federalism by applying these rules strictly.

In contrast, in the core state function context Congress must expend significant resources to specify every state function it wishes to regulate. Therefore, it is more appropriate to weigh costs against federalism interests. All three of these rules thus can be seen to balance protection of state sovereignty against decision and error costs; the ease of complying with the Eleventh and Fourteenth Amendment rules simply means that the Court can be stricter regarding the requirements for a clear statement.

An interpretation of Gregory that assumes that an explicit statutory exemption excludes a core state function from coverage,

${ }^{53}$ See note 15 and accompanying text.

${ }^{54}$ See note 56 and accompanying text. In Seminole Tribe of Florida $v$ Florida, $116 \mathrm{~S}$ Ct 1114, 1124-32 (1996), the Court invalidated a clearly stated infringement on state sovereignty because it was enacted under the Indian Commerce Clause, not the Fourteenth Amendment.

${ }^{5 s}$ See notes 11-16 and accompanying text.

${ }^{3}$ In the Fourteenth Amendment context, courts will look to the functions actually abrogated by the statute as well as the statutory text in determining whether Congress has acted pursuant to its Fourteenth Amendment power. See Woods $v$ Cloyd W. Miller Co, 333 US 138, 144 (1948) ("[T]he constitutionality of action taken by Congress does not depend on recitals of the power which it undertakes to exercise."). However, a clear statement in the statute generally is interpreted as a strong indication that Congress has exercised this power in a valid manner. See, for example, Clark v California, 123 F3d 1267, 1271 (9th Cir 1997) (In determining whether the ADA was enacted pursuant to Congress's Fourteenth Amendment power, the Ninth Circuit stated that great deference is given to congressional statements.). 
unless it is unambiguously clear that it does not, is also appropriate in light of federalism interests and decision and error costs. This aspect of the Gregory rule is likely to be most important in instances where Congress seeks to exempt specific state functions from the reach of a generally applicable statute. In such cases, legislative decision costs may be decreased by this rule because Congress is probably more capable of drafting individual exemptions from a statute's coverage with an appropriate degree of specificity than enumerating the entire range of state functions affected by the statute, at least in the case of broadly applicable statutes. In addition, the rule provides significant protection for federalism by permitting courts to construe statutory exemptions broadly. Thus, courts can use this rule to exclude a greater range of core state functions from coverage. This broad interpretation of statutory exemptions will only be limited by the restriction that those functions clearly not included in the exemptions are still covered by the statute.

While this analysis has not focused on the question of the range of "core state functions" to which clear statement review applies, the lenient interpretation of the Gregory rule renders that issue irrelevant in many circumstances. In the absence of exemptions creating ambiguity as to a generally applicable statute's coverage, clear language describing the statute's broad sweep will be sufficient to permit federal interference in all state functions, including any function that might be considered a "core state function."

If, however, the statute does not state that it is applicable to all state functions, the range of core state functions becomes important. The Gregory clear statement rule does not apply to state operations that are not core state functions; thus, the categorization of the affected function is a threshold inquiry.

Assuming arguendo that the affected state function is a core state function, the lenient Gregory rule provides a straightforward technique of statutory construction, one that properly balances federalism and legislative decision and error costs. In cases where the plain meaning of a narrowly applicable statute logically encompasses the affected state function, the lenient Gregory clear statement rule will automatically be satisfied. However, when it is ambiguous whether the plain meaning of the statute includes the function at issue, a definitive Gregory analysis is infeasible because of the Court's failure to delineate the category of core state functions. 


\section{The Gregory Clear Statement Rule Will Have a Positive Influence on the Future Drafting of Statutes}

The analysis of the clear statement rule outlined above has important ramifications for the drafting of new statutes. It suggests that Congress need not incur high decision costs by specifically enumerating every state function to which a statute applies. Instead, because the plain meaning canon will be applied to a statute's description of its coverage, Congress need only draft clearly worded statutory language broad enough to logically include the state functions it seeks to regulate. In addition, if Congress wishes to avoid intruding upon particular core state functions, this Comment's interpretation of the clear statement rule puts Congress on notice that it should describe a statute's coverage narrowly or explicitly exempt the functions from coverage.

Congress must also take care to draft exemptions to statutes precisely, with the specificity appropriate to the statute's desired coverage. If a statutory exemption is too narrow, courts may interpret the statute to regulate certain state functions that Congress intended to exempt. In contrast, if an exemption is too vague, courts may read it to preclude Congress from infringing upon state functions that it intended to include in the statute's coverage.

This interpretation of the clear statement rule is advantageous for several reasons. Guided by the knowledge that plain meaning analysis will be applied to its statutory language, Congress will enjoy reduced decision costs, and also will engage in the deliberation necessary to protect federalism interests. In addition, courts will be able to apply plain meaning analysis to determine congressional intent, thereby reducing the likelihood of inconsistent statutory interpretation. By reducing the likelihood that a statute will be narrowed in a manner that Congress did not intend, this rule also decreases the waste of judicial and legislative resources inherent in the process of invalidation and subsequent congressional amendment. Finally, the flexibility inherent in permitting generally worded statutory language to overcome clear statement review reduces the risk of ossification and permits adaptation of statutes to changing circumstances.

\section{THE APPLICABILITY OF THE AMERICANS WITH DISABILITIES} ACT TO PRISONERS WITH DISABILITIES

A controversial application of the Gregory clear statement rule involves the availability of relief under the public services 
provision of the ADA to disabled persons incarcerated in state prisons. This issue is examined below.

\section{A. Introduction}

Federal courts disagree about whether the ADA applies to disabled persons incarcerated in state prisons. ${ }^{57}$ This disagreement is a vivid example of the undesirable consequences that have resulted from the courts' inconsistent interpretation of the Gregory clear statement rule. To understand better the nature of the dissension, this Comment will discuss briefly the history of the ADA before applying the Gregory rule to determine the scope of the ADA's applicability.

Prior to enactment of the ADA, the rights of persons with disabilities were protected incompletely. ${ }^{58}$ For example, the Rehabilitation Act of $1973^{59}$ only provided disabled persons with protection against discrimination by federally funded entities, and was not enforceable against state or local governments or private entities that did not receive federal funds. ${ }^{60}$ Other federal statutes, such as the Education of All Handicapped Children Act ${ }^{61}$ the Developmentally Disabled Assistance and Bill of Rights Act, ${ }^{62}$ and the Voting Accessibility for the Elderly and Handicapped Act, ${ }^{63}$ addressed specific problems faced by the disabled, but did not mandate a comprehensive ban on discrimination. ${ }^{64}$ Thus, persons with disabilities had no protection from discrimination in many areas, including private employment, transportation, public accommodations, and state and local activities and services. ${ }^{65}$

Recognizing the inadequate protection afforded to disabled persons by existing legislation, Congress enacted the ADA. The

${ }^{57}$ See note 6.

${ }^{s s}$ See Dick Thornburgh, The Americans with Disabilities Act: What It Means to All Americans, 64 Temple L Rev 375, 377 (1991) ("The ADA overcomes our past failure to eliminate attitudinal, architectural, and communication barriers in employment, transportation, public accommodations, public services, and telecommunications.").

${ }^{50}$ Pub L No 93-112, 87 Stat 355 (1973), codified as amended at 29 USC §§ 790-94 (1994).

$\infty$ Title V of the Rehabilitation Act expressly applies only to recipients of federal funds, federal employers, and federal contractors. See 29 USC $\$ \$ 790-94$.

${ }^{61}$ Pub L No 94-142, 89 Stat 773 (1975), as amended by the Education of the Handicapped Act, Pub L No 101-476, 104 Stat 1103 (1990), codified as amended at 20 USC §§ 1400-20 (1994).

2 Pub L No 94-103, 89 Stat 486 (1975), codified as amended at 42 USC $\S 6000$ (1994). (1994).

๘ Pub L No 98-435, 98 Stat 1678 (1984), codified as amended at 42 USC § 1973ee

6) See Lowell P. Weicker, Jr., Historical Background of the Americans with Disabilities Act, 64 Temple L Rev 387, 387-89 (1991).

${ }^{\infty}$ Id at 389. 
ADA was modeled on the Rehabilitation Act and was intended to complement that statute by extending coverage beyond the federal sector. ${ }^{66}$ Congress intended the ADA to "provide a clear and comprehensive national mandate for the elimination of discrimination against individuals with disabilities ${ }^{967}$ by extending protection of the disabled into a number of areas, including employment, ${ }^{68}$ public services, ${ }^{69}$ public accommodations, ${ }^{70}$ and telecommunications. ${ }^{71}$

Following the ADA's enactment, commentators speculated that disabled persons incarcerated in state prisons would be able to rely upon Title II of the statute (the public services provision) to request special accommodations for their disabilities. ${ }^{72}$ However, federal courts have split over whether Title II relief is available to prisoners. ${ }^{73}$ Courts refusing to extend Title II coverage to disabled inmates have found that the statute's broad language does not constitute a "clear statement" of congressional intent to interfere with the core state function of operation of state prisons. ${ }^{74}$ In contrast, courts granting prisoners the right to seek relief under the ADA have found a clear statement in the statutory text. ${ }^{75}$

${ }^{6}$ See Nancy Lee Jones, Overview and Essential Requirements of the Americans With Disabilities Act, 64 Temple L Rev 471, 475-76 (1991).

67 42 USC \& 12101(b)(1) (1994).

${ }^{6}$ See 42 USC \$\$ 12111-17 (1994).

${ }^{6}$ See 42 USC $\$$ 12131-34 (1994).

${ }^{70}$ See 42 USC $\$ 12181-89$ (1994).

${ }^{71}$ See 47 USC $\S \$ 225,610$ (1994).

${ }^{72}$ See, for example, John Boston and Daniel E. Manville, Prisoners' Self-Help Litigation Manual 75-76 (Oceana 3d ed 1995) (The ADA's definition of a public entity "clearly includes correction departments and other agencies that operate prisons and jails."); Elaine Gardner, The Legal Rights of Inmates with Physical Disabilities, 14 SLU Pub L Rev 175, 193-94 (1994) ("There initially appeared to have been some confusion . . . regarding the ADA and its applicability to inmates with disabilities. . . . [T]his type of confusion as to the ADA's applicability and requirements is sure to diminish."); Susan $P$. Sturm, The Legacy and Future of Corrections Litigation, 142 U Pa L Rev 639, 733 (1993) ("Advocates ... observe the potential to address the problems of AIDS in prison via the [ADA].").

${ }^{73}$ See note 6 and accompanying text.

"See, for example, Torcasio v Murray, 57 F3d 1340, 1346-47 (4th Cir 1995) (holding that, because of the impact that the ADA would have on the management of state prisons and, therefore, on federal-state relations, the "broad, non-specific" language of the ADA does not clearly subject state prisons to its enactments).

${ }^{75}$ See, for example, Yeskey v Pennsylvania Department of Corrections, 118 F3d 168, 170-71 (3d Cir 1997), citing 42 USC $\$ 12132$ (holding that language in the ADA that states that the ADA covers persons participating in the "[s]ervices, programs or activities of a public entity" constitutes a clear statement of congressional intent to include state prisons in the Act). 


\section{B. Title II: The Public Services Section of the ADA}

The language of Title $\mathrm{II}^{76}$ of the ADA provides disabled persons with comprehensive access to programs and services offered by state and local governments. ${ }^{77}$ The relevant language in Title II states:

[N]o qualified individual with a disability shall, by reason of such disability, be excluded from participation in or be denied the benefits of the services, programs, or activities of a public entity, or be subjected to discrimination by any such entity. ${ }^{78}$

"Public entity" is broadly defined to include "any State or local government" and "any department, agency, special purpose district, or other instrumentality of a State or States or local government. ${ }^{.79} \mathrm{~A}$ "qualified individual with a disability" is defined as:

[A]n individual with a disability who, with or without reasonable modifications to rules, policies, or practices, the removal of architectural, communication, or transportation barriers, or the provision of auxiliary aids and services, meets the essential eligibility requirements for the receipt of services or the participation in programs or activities provided by a public entity. ${ }^{80}$

The only specific exception to Title II's coverage is the exclusion of certain disorders from the category of "disabilities. ${ }^{n 11}$ The excluded disorders include homosexuality and bisexuality, ${ }^{82}$ as well as sexual behavior disorders, certain psychological disor-

${ }^{76}$ Prisoners with disabilities seeking relief under the ADA typically sue under Title II (the public services provision), although a few suits arising from prison employment have been brought under Title I (the employment provision). See, for example, White $v$ Colorado, 82 F3d 364, 367 n 5 (10th Cir 1996) (rejecting an injured inmate's claim that Title I of the ADA applied to the inmate's claim for relief under the ADA). The discussion that follows focuses on Title II.

$\pi$ See 42 USC $\$ \$ 12131-34$.

${ }^{78} 42$ USC § 12132.

72 USC \& $12131(1)$.

${ }^{80} 42$ USC \& 12131(2). The term "disability" is defined to include "a physical or mental impairment that substantially limits one or more of the major life activities of such individual; a record of such an impairment; or being regarded as having such an impairment." 28 CFR § 35.104 (1996). The regulations go on to detail certain types of disabilities. See id. Although "essential eligibility requirements" are not defined in the statute, the $\mathrm{ADA}$ 's implementing regulations state that in order to meet these requirements, the person seeking ADA relief must have been eligible for participation in a public service or activity but for her disability. See id.

si 42 USC § 12211.

See 42 USC $\$ 12211$ (a). 
ders, and psychoactive substance abuse disorders resulting from current use of illegal drugs. ${ }^{83}$ Other than these exceptions, the ADA does not explicitly exclude any other person with a mental or physical disorder from protection under the statute.

Congress included several provisions making Title II enforceable against the states. First, Congress enacted the ADA pursuant to its authority under both the Fourteenth Amendment and the Interstate Commerce Clause ${ }^{84}$ In addition, Title II specifically abrogates the states' 'sovereign immunity under the Eleventh Amendment. ${ }^{85}$ Finally, Title II states that the remedies available in any action against a state are the same as those available in an action under the ADA against any other public or private entity. ${ }^{86}$

\section{Decisions Holding That the ADA Is Inapplicable to Disabled Inmates in State Prisons}

Numerous federal courts, including the Fourth Circuit and district courts in the Fifth Circuit, have refused to find that Title II of the ADA provides a clear statement of congressional intent to extend coverage of the statute to disabled inmates in state prisons. ${ }^{87}$ These courts typically rely on two rationales. First, Ti-

${ }^{8}$ See 42 USC $\S 12211(b)$. In its entirety, this provision states:

Under this chapter, the term "disability" shall not include: (1) transvestism, transsexualism, pedophilia, exhibitionism, voyeurism, gender identity disorders not resulting from physical impairments, or other sexual behavior disorders; (2) compulsive gambling, kleptomania, or pyromania; or (3) psychoactive substance use disorders resulting from current illegal use of drugs.

For a discussion of this section and its implications, see Adrienne L. Hiegel, Note, Sexual Exclusions: The Americans with Disabilities Act as a Moral Code, 94 Colum L Rev 1451 (1994).

84 In its statement of the ADA's purpose, Congress stated that the ADA was intended "to invoke the sweep of congressional authority, including the power to enforce the fourteenth amendment and to regulate commerce, in order to address the major areas of discrimination faced day-to-day by people with disabilities." 42 USC § 12101(b)(4). At least one court has questioned whether Title II is a valid exercise of Congress's Fourteenth Amendment power. See Pierce v King, 918 F Supp 932, 940 (E D NC 1996) ("Unlike traditional anti-discrimination laws, the ADA demands entitlement in order to achieve its goals. This the Fourteenth Amendment cannot authorize.").

85 "A State shall not be immune under the eleventh amendment to the Constitution of the United States from an action in Federal or State court of competent jurisdiction for a violation of this chapter." 42 USC $\S 12202$.

${ }_{86}$ "In any action against a State for a violation of the requirements of this chapter, remedies (including remedies both at law and in equity) are available for such a violation to the same extent as such remedies are available for such a violation in an action against any public or private entity other than a State." Id.

${ }_{87}$ See Amos $v$ Maryland Department of Public Safety and Correctional Services, 126 F3d 589, 590-91 (4th $\mathrm{Cir}$ 1997) (thirteen inmates with a variety of disabilities); Torcasio, 57 F3d at 1342, 1344 (obese inmate); Boblett $v$ Angelone, 957 F Supp 808, 812 (W D Va 
tle II's coverage of "services, programs or activities" of all "public entities" does not clearly include the operation of state prisons. ${ }^{88}$ Second, disabled prisoners are not "qualified individuals with disabilities" for the purposes of ADA eligibility. ${ }^{89}$ Some courts also note that prison officials' right to qualified immunity may bar prisoner suits in certain circumstances. ${ }^{90}$ However, these courts generally concede that a clear statement will supersede a defense of qualified immunity. ${ }^{91}$

The Fourth Circuit's decision in Torcasio v Murray $y^{92}$ illustrates the reasoning of courts that have held that the ADA does not apply to state prisons. In Torcasio, the plaintiff (an obese inmate incarcerated in a Virginia state prison) requested modifications to his cell, bathroom facilities, and lobby and recreational areas to accommodate his disability ${ }^{93}$ When prison officials failed to fully grant his requests, the inmate filed an action under Title II of the $\mathrm{ADA} .^{94}$

In determining whether the inmate was entitled to seek relief under the ADA, the Fourth Circuit applied the Gregory clear statement rule. ${ }^{95}$ The court first found that management of state prisons is a core state function to which the clear statement rule applies. ${ }^{96}$ The court took care to identify the unique status of

1997) (inmate with knee problems); Pierce, 918 F Supp at $937-38$ (disabled inmate claiming prison refused to make accommodation to enable him to participate in certain work programs); Staples $v$ Virginia Department of Corrections, 904 F Supp 487, 490 (E D Va 1995) (paraplegic inmate). See also Gorman v Bartch, 925 F Supp 653, 655-56 (W D Miss 1996) (holding that wheelchair-bound arrestee injured while being transported in police van not equipped with wheelchair restraints was not a "qualified individual" under the ADA).

${ }^{88}$ Amos, 126 F3d at 596; Torcasio, 57 F3d at 1342; Boblett, 957 F Supp at 812; Staples, 904 F Supp at 490.

Amos, 126 F3d at 596; Torcasio, 57 F3d at 1347. See also Gorman, 925 F Supp at 655 ('It strains the [ADA] to talk about [p]laintiffs 'eligibility' to be arrested and taken to jail or to 'participate' in being arrested.").

${ }^{9}$ See, for example, Torcasio, 57 F3d at 1343 (finding that prison officials could have believed that their denial of an obese inmate's requests for accommodations did not violate the inmate's rights, and therefore that the officials were protected by qualified immunity).

st See, for example, id at 1343-44.

${ }^{92} 57$ F3d 1340 (4th Cir 1995).

${ }^{93}$ Id at 1342.

${ }^{*}$ Id at $1342-43$.

${ }^{95}$ Id at 1344-46.

${ }^{36}$ Id at 1345 ("It is difficult to imagine an activity in which a State has a stronger interest, or one that is more intricately bound up with state laws, regulations, and procedures, than the administration of its prisons."), citing Preiser v Rodriguez, 411 US 475, 491-92 (1973). The Fourth Circuit based this finding on its interpretation of the range of core state functions, which the Gregory Court had left open. See note 7. 
state prisons as an area where courts are especially hesitant to permit federal interference. ${ }^{97}$

The Torcasio court then examined the language of Title II of the ADA. While conceding that the "seemingly absolute" language appeared to include state prisons, the court refused to find that Title II's "broad, non-specific" language clearly established the inmate's right to ADA relief. ${ }^{98}$ Instead, the court found that while the definition of "public entity" in Title II is expansive, "prisons are not expressly mentioned in the statute, and they certainly do not come readily to mind as the type of institution covered [by the ADA]." ${ }^{\prime \prime 9}$ The Fourth Circuit thus interpreted clear statement review to require statutory language that expressly stated that the ADA applies to state prisons.

The Fourth Circuit also rejected the inmate's contention that Congress intended the phrase "qualified individual with a disability" in Title II to include disabled prisoners. ${ }^{100}$ The court reasoned that the terms "eligible" and "participate" in the definition of this phrase imply a voluntary choice on the part of the disabled person, and do not logically refer to prisoners being held against their will. ${ }^{101}$ Thus, the court concluded that prisoners cannot meet the "essential eligibility requirements" for receipt of public services. ${ }^{102}$

In summary, courts that refuse to find prisoners with disabilities eligible for ADA relief have concluded either that the ADA's statutory language is not a clear statement of its applicability to state prisons or that disabled prisoners are not "qualified individuals with disabilities." When courts fail to find a clear statement in the broad language of Title II, this implies that they require a much clearer and perhaps explicit statement that the statute applies to state prisoners. These courts consider the federalism interests affected by the ADA to be much more important than the increase in legislative decision and error costs necessitated by a requirement for specific enumeration.

" See Torcasio, 57 F3d at 1346. The court stated that "principles of comity and federalism apply with special force in the context of correctional facilities." Id at 1346. The court also noted that if it had been required to decide whether a state entity other than a prison might be found liable for the acts in question, it "might come to [its] task with a somewhat different jurisprudential mindset." Id at 1344. However, the court did not elaborate on this distinction.

${ }^{98}$ Id at 1346-47.

${ }^{99}$ Id at $1346 \mathrm{n} 5$.

${ }^{100}$ See id at 1347.

${ }^{101}$ See id.

${ }^{102}$ See id. 


\section{Decisions Holding That the ADA Is Applicable to Disabled Inmates in State Prisons}

In contrast to the Fourth Circuit and the courts following its reasoning, several federal courts, including the Second, Third, Seventh, Eighth, and Ninth Circuits as well as district courts in the Sixth and Eleventh Circuits, have upheld the applicability of the ADA to inmates of state prisons. ${ }^{103}$ These courts have advanced three arguments in support of their decisions. First, the language of Title II satisfies clear statement review. Second, the ADA explicitly states that it shall provide persons with disabilities at least as much protection as the Rehabilitation Act, which clearly applies to correctional institutions. Third, the regulations implementing the ADA mandate the statute's applicability to state prisons. The validity of using these arguments to overcome the Gregory test varies significantly; examining the statutory language to find a clear statement is clearly proper, while examining the $\mathrm{ADA}$ 's regulations is just as clearly incorrect.

First, despite the lack of specific enumeration in Title II, several courts have held that the statute's language is sufficiently precise to overcome clear statement review. ${ }^{104}$ These courts rely upon the ADA's statement that it reaches any service, program, or activity offered by a "public entity" (where "public

\footnotetext{
${ }^{103}$ See Armstrong $v$ Wilson, 124 F3d 1019 (9th Cir 1997) (certifying class of present and future inmates with mobility, sight, hearing, learning or kidney disabilities); Clark $v$ California, 123 F3d 1267 (9th Cir 1997); Yeskey, 118 F3d at 174 (Inmate with hypertension was denied entrance to prison's Motivational Boot Camp.); Crawford, 115 F3d at 481 (Prisoner was denied access to a variety of programs because of his blindness.); Duffy $v$ Riveland, 98 F3d 447, 455 (9th Cir 1996) (Deaf inmate was denied interpreter at disciplinary hearings.); Randolph $v$ Rogers, 1997 US Dist LEXIS 15892, *24 (E D Mo) (Hearing impaired inmate was denied interpreter.); Herndon $v$ Johnson, 970 F Supp 703, 703-04 (E D Ark 1997) (Inmate with fused spine was denied assistive devices.); Saunders $v$ Horn, 960 F Supp 893, 901 (E D Pa 1997) (Disabled inmate was denied orthopedic shoes and brace.); Carty $v$ Farrelly, 957 F Supp 727, 741 (D Virgin Islands 1997) (Inmate who used cane placed with mentally ill inmate because officials saw cane as a security threat.); Kaufman $v$ Carter, 952 F Supp 520, 529-31 (W D Mich 1996) (bilateral amputee inmate); Clark v California, 1996 US Dist LEXIS 21630, *3-4 (N D Cal) (developmentally disabled inmates), affd, 123 F3d 1267 (9th Cir 1997); Niece v Fitzner, 941 F Supp 1497, 1507-11 (E D Mich 1996) (action brought by prisoner's deaf, wheelchair-bound fiancé); Bullock $v$ Gomez, 929 F Supp 1299, 1302-03 (C D Cal 1996) (HIV-positive inmate); Dean v Knowles, 912 F Supp 519, 521 (S D Fla 1996) (same); Rewolinski v Morgan, 896 F Supp 879, 881 (E D Wis 1995) (deaf inmate); Clarkson v Coughlin, 898 F Supp 1019, 1037 (S D NY 1995) (hearing-impaired inmates); Noland $v$ Wheatley, 835 F Supp 476, 483 (N D Ind 1993) ("semi-quadriplegic" inmate); Outlaw $v$ Dothan, 1993 US Dist LEXIS 21063, *8-11 (M D Ala) (prisoner with artificial leg who could not use ceramic tile shower). See also Fennell $v$ Simmons, 951 F Supp 706, 708 (N D Ohio 1997) (applying the ADA to county jails).

${ }^{104}$ See Armstrong, 124 F3d at 1024; Yeskey, 118 F3d at 170; Crawford, 115 F3d at 485; Duffy, 98 F3d at 452; Randolph, 1997 US Dist LEXIS 15892 at *22-24; Herndon, $970 \mathrm{~F}$ Supp at 706; Saunders, 960 F Supp at 901; Clark, 1996 US Dist LEXIS 21630 at *3; Niece, 941 F Supp at 1506.
} 
entity" is defined explicitly to include a state and all its instrumentalities). ${ }^{105}$ Courts also cite the ADA's broad purpose and expansive language for the proposition that Congress intended to provide protection from discrimination to all disabled persons. Furthermore, Congress did not include any provision excluding state prisons or inmates from ADA coverage. ${ }^{106}$ Finally, one court has noted that the ADA includes only a few specific exceptions to its broad grant of rights. ${ }^{107}$ That court applied the canon expressio unius est exclusio alterius to infer that the $\mathrm{ADA}$ is applicable to any disabled person whose disability does not fall into one of these exceptions. ${ }^{108}$ In finding a clear statement in the language of Title II, several courts explicitly rejected the Fourth Circuit's holding in Torcasio, thus implicitly adopting the lenient reading of the Gregory clear statement rule proposed in Part I of this Comment. ${ }^{109}$

Second, courts that uphold Title II's applicability to state prisons also observe that Congress specifically directed that the ADA was to provide at least as much protection as the Rehabilitation Act and its regulations, which mandate that statute's applicability to correctional departments and facilities. ${ }^{110}$ Some of these decisions rely upon Rehabilitation Act case law. ${ }^{111}$ In addition, in Helen L. $v$ DiDario, ${ }^{112}$ a non-prison case, the Third Circuit reasoned that Congress's patterning of the ADA on the Rehabilitation Act gave the latter statute's regulations the "force of law" in interpreting the ADA. The Helen $L$. court analogized Congress's explicit approval of the Rehabilitation Act and its regula-

${ }^{105}$ See Armstrong, 124 F3d at 1024; Yeskey, 118 F3d at 170; Crawford, 115 F3d at 485; Randolph, 1997 US Dist LEXIS 15892 at *22-24; Saunders, 960 F Supp at 901; Clark, 1996 US Dist LEXIS 21630 at *11-12; Niece, 941 F Supp at 1506. See also notes 77-79 and accompanying text.

${ }^{106}$ See Armstrong, 124 F3d at 1024; Randolph, 1997 US Dist LEXIS 15892 at *22; Kaufman, 952 F Supp at 529; Niece, 941 F Supp at 1506. This argument is reinforced by Supreme Court precedent indicating that "remedial legislation should be construed broadly to effectuate its purposes." Niece, 941 F Supp at 1505, quoting Tcherepnin $v$ Knight, 389 US 332, 336 (1967).

${ }^{107}$ See Kaufman, $952 \mathrm{~F}$ Supp at 529. For a discussion of the ADA's exceptions, see notes $81-83$ and accompanying text.

${ }^{108}$ See Kaufman, 952 F Supp at 529.

${ }^{109}$ See Armstrong, 124 F3d at 1023-24; Yeskey, 118 F3d at 173; Randolph, 1997 US Dist LEXIS 15892 at *23; Herndon, 970 F Supp at 706; Saunders, 960 F Supp at 901.

${ }^{100}$ See Armstrong, 124 F3d at 1023; Saunders, 960 F Supp at 897; Kaufman, 952 F Supp at 530-31, citing Bonner v Lewis, 857 F2d 559, 563 (9th Cir 1988). See also Jones, 64 Temple $L$ Rev at 475-76 (cited in note 66).

${ }^{11}$ See Armstrong, 124 F3d at 1023, citing Bonner, 857 F2d at 562-63; Duffy, 98 F3d at 452-56; Saunders, 960 F Supp at 897-98.

${ }^{112} 46$ F3d 325, 332 (3d Cir 1995) (finding resident of nursing home protected by the ADA), cert denied as Pennsylvania Secretary of Public Welfare v Idell S., 116 S Ct 64 (1995). 
tions in the ADA to the judicial deference granted to regulations approved by Congress when it reenacts statutes. ${ }^{113}$

Third, courts focus on the regulations implementing Title II, which apply the ADA to state correctional facilities. ${ }^{114}$ These courts rely on the Cheoron principle of judicial deference to administrative interpretations of ambiguous statutes. ${ }^{115}$ In an apparent oversight, the question of whether the Gregory clear statement rule takes priority over Cheuron deference has not been discussed in these decisions. ${ }^{116}$ To date, only a few federal courts have examined this issue; however, commentators and courts have generally concluded that clear statement review trumps Chevron deference. ${ }^{117}$ If so, the ADA's regulations should be given no weight in determining whether the statute overcomes clear statement review.

In summary, courts that find the ADA applicable in the state prison context rely upon three distinct rationales. First, they find that Title II constitutes a clear statement. Second, they analogize the ADA to the Rehabilitation Act (the statute upon which the ADA was modeled) and observe that the regulations implementing the latter statute extend coverage to correctional institutions. Third, they defer to the regulations implementing the ADA, which explicitly mandate the statute's applicability to prisons. In rejecting a requirement for specific enumeration, the courts

${ }^{113}$ See id, citing United States $v$ Board of Commissioners of Sheffield, 435 US 110, 134 (1978), and Don E. Williams Co v Commissioner, 429 US 569, 574-77 (1977).

${ }^{114}$ See Yeskey, 118 F3d at 170-71; Herndon, 970 F Supp at 706-07; Kaufman, 952 F Supp at 530; Clark, 1996 US Dist LEXIS at *12; Niece, 941 F Supp at 1506-07; Noland, 835 F Supp at 483.

${ }^{115}$ See Herndon, $970 \mathrm{~F}$ Supp at 707, citing Cheuron USA Inc $v$ National Resources Defense Council, Inc, 467 US 837, 843-44 (1984), for the proposition that Congress's grant of regulatory authority to the Department of Justice must be given controlling weight unless the resulting regulations are "arbitrary, capricious, or manifestly contrary" to the ADA. See also Noland, 835 F Supp at 483.

${ }^{116}$ See Teper $v$ Miller, 82 F3d 989, 998 (11th Cir 1996) (terming this a "knotty issue of jurisprudence"). See also Paul McGreal, Some Rice With Your Chevron?: Presumption and Deference in Regulatory Preemption, 45 Case W Res L Rev 823, 825-28 (1995) (noting an unresolved tension between the presumption against federal preemption of traditional areas of state law and Chevron deference).

${ }^{117}$ See Bernard W. Bell, Using Statutory Interpretation to Improve the Legislative Process: Can It Be Done in the Post-Chevron Era?, $13 \mathrm{~J} \mathrm{~L} \&$ Politics 105, 132-33 (1997) (noting that Chevron does not frustrate interpretive rules such as clear statement rules, because they are applied at Step I of the Cheuron test); Cass R. Sunstein, Law and Administration After Chevron, 90 Colum L Rev 2071, 2113-14 (1990) (noting that Cheuron deference will probably not prevail over constitutionally based rules of interpretation such as the clear statement principle), citing California State Board of Optometry $v$ Federal Trade Commission, 910 F2d 976, 981-82 (DC Cir 1990), and Amalgamated Transit Union $v$ Skinner, 894 F2d 1362, 1368 (DC Cir 1990); Dan Kahan, Is Chevron Relevant to Criminal Law?, 110 Harv L Rev 469, 504-06 (1996) (stating that when issues of federalism are implicated, the clear statement rule should take priority over Chevron deference). 
finding a clear statement implicitly recognize that Congress's resources for drafting statutes are limited, and that this justifies a balancing of federalism interests against legislative decision and error costs.

\section{E. Title II of the ADA Satisfies Clear Statement Review and Thus Applies to Persons With Disabilities Incarcerated in State Prisons}

Application of the Gregory clear statement rule to Title II of the ADA indicates that the statute's language suffices as a clear statement of congressional intent to affect the management of state prisons. First, the plain meaning of Title II's description of the extent of its coverage includes state prisons and prisoners with disabilities. Second, Title II does not contain any exception to its coverage that might render ambiguous the inclusion of state prisoners.

The first part of the Gregory test requires analyzing the plain meaning of Title II's description of coverage. As discussed in Part II.B, the statute's coverage is very expansive: Title II's definition of a "public entity" includes "any State or local government," as well as "any department, agency, special purpose district, or other instrumentality of a State or States or local government."118 The plain meaning of this language logically includes all state-run organizations, including state correctional institutions. Thus, Title II clearly states that it reaches the management of state prisons.

Despite the statute's seemingly all-encompassing reach, Title II does include some provisions that might be construed to limit its coverage. The statute only applies to the "services, programs, or activities" of a public entity. ${ }^{119}$ In addition, Title II requires that a person seeking relief under the ADA be a "qualified individual with a disability." person must meet the "essential eligibility requirements for the receipt of services or the participation in programs or activities provided by a public entity."121 In Torcasio, the Fourth Circuit focused on these provisions and expressed doubt as to whether Congress intended to reach disabled inmates in state prisons when it enacted the ADA. ${ }^{122}$

${ }^{118} 42$ USC § 12131(1) (emphasis added).

${ }^{119} 42$ USC \$ 12132.

${ }^{120} \mathrm{Id}$.

${ }^{121} 42$ USC \$ 12131(2).

${ }^{122}$ See Torcasio, 57 F3d at 1346-47, citing 29 USC §§ 12131(2), 12132. 
These provisions create two potential sources of ambiguity that might preclude a finding of a clear statement. First, is operation of a prison a "service, program, or activity" of a state government? And second, are disabled prisoners "qualified individuals" who meet the "essential eligibility requirements" for participation in these programs?

To answer these questions, it is important to differentiate between the activities that occur in correctional facilities. For instance, the plain meaning of "service, program, or activity" unambiguously includes activities such as vocational and educational programs offered by state prisons. In addition, if the only eligibility requirement for participation in these programs is that the person seeking to participate is incarcerated, all disabled prisoners automatically meet the "essential eligibility requirements" prong of the ADA. Thus, this requirement does not prevent disabled prisoners from requesting special accommodations to enable their participation in these programs.

Other areas of prison operation, such as the management of prisoners' living quarters and bathroom facilities, present a more difficult question. Whether the phrase "service, program, or activity" extends to basic prison operations seems unclear. This apparent lack of clarity may preclude finding a clear statement of Title II's applicability in this area. However, the expansive definition of "public entity" in the statute can logically be read to include a prison and all its facilities, and thus when read in context the "services, programs, or activities" of "public entities" logically include all operations of state prisons. Therefore, including all prison operations in the category of state functions covered by Title II while excluding the management of prison living facilities from the category of "services, programs, or activities" would lead to a conflict that Congress likely did not intend. ${ }^{123} \mathrm{~A}$ broad construction of Title II also coincides with the purpose of the ADA stated in the text of the statute, which is the elimination of discrimination against all individuals with disabilities. In light of this, Title II should be construed to satisfy the first part of the Gregory test.

Title II also satisfies the second part of the Gregory clear statement test. The statute includes no provisions exempting any branch of state or local government from its requirements. Thus, there are no provisions that could make inclusion of the activity

\footnotetext{
${ }^{123}$ This interpretation is consistent with the "whole act" canon of construction, which states that one provision of a statute should not be read in such a manner as to negate or derogate another provision. See Eskridge and Frickey, Cases and Materials on Legislation at 643-45 and citations therein (cited in note 11).
} 
ambiguous. The only explicit exception to Title II's coverage pertains to persons with certain physical and psychological disorders, a category that does not include prisoners with disabilities (although prisoners with these disorders would not be entitled to relief under the ADA). ${ }^{124}$ Thus, because there is no statutory exception that could make ambiguous the inclusion of prisoners with disabilities within the class of persons eligible for ADA relief, Title II satisfies the second step of clear statement review. Because Title II passes both steps of the Gregory test, prisoners with disabilities should be entitled to ADA coverage in all areas of prison operation.

A comparison of this Comment's analysis with the approaches taken by the courts illustrates errors in reasoning by courts on both sides of the debate. The Fourth Circuit in Torcasio and the courts following that decision err in finding no clear statement in the text of the ADA. In the absence of an exception that could conceivably include the core state function at issue, broad, unambiguously worded statutory language-such as that found in the ADA-is sufficient to satisfy clear statement review. In addition, these courts fail to recognize that the question of whether prisoners are "qualified individuals with disabilities" is not distinct from clear statement review. Instead, this issue must be analyzed in the context of determining whether the ADA provides a clear congressional statement of applicability to prisoners with disabilities. Finally, because Congress has stated clearly its intent to extend ADA protection to prisoners with disabilities, courts may not refuse to grant ADA relief by arguing that prison programs are benefits and not entitlements, or that prisoners are likely to be harmed rather than helped by the ADA. Instead, courts must apply the ADA to disabled prisoners' claims, and may only examine whether the prisoners' requested accommodations for their disabilities are "reasonable modifications" under the requirements of the statute and its regulations.

Courts finding a clear statement in the statutory language of the ADA generally track the reasoning of the analysis in this Comment. However, some of these courts also rely upon erroneous rationales to support their holdings. In particular, courts that seek a clear statement in the legislative history or regulations implementing the ADA fail to recognize that clear statement review precludes examination of any source of statutory interpretation outside the four corners of the statute. In addition, given the importance of the federalism interests protected by the

${ }^{124}$ See notes $81-83$ and accompanying text. 
clear statement rule, courts apparently have erred in assuming that Chevron deference to administrative interpretation of the ADA trumps clear statement review. ${ }^{125}$

\section{CONCLUSION}

This Comment analyzes the Supreme Court's description of clear statement review in Gregory to develop a test for determining whether Congress has expressed plainly its intent to infringe upon core state functions. The test consists of two parts. First, plain meaning analysis is applied to a statute's description of its coverage. Therefore, broad unenumerated statutory language will suffice as a clear statement, as long as the plain meaning of the language includes the state function being regulated. Second, exemptions to a statute's coverage will be read to create ambiguity and preclude a finding of a clear statement, unless the exemption is clearly inapplicable to the state function at issue. This approach properly balances the federalism interests protected by the clear statement rule against the need to control legislative decision and error costs.

Application of the Gregory clear statement rule to Title II of the ADA indicates that persons with disabilities incarcerated in state prisons should be eligible for ADA relief. This eligibility is limited only by the requirement that they fulfill the conditions for Title II relief; that is, they must have a "disability" as defined in the ADA.

The interpretation of the Gregory clear statement rule described in this Comment has several advantages over the versions of the rule currently applied by the courts. While this rule will not provide unambiguous interpretations of all statutes in all cases, its increased precision decreases the likelihood of judicial disagreement over the coverage of broadly worded statutes. In addition, this rule reduces decision and error costs in several ways: it permits Congress to affect a range of state functions without drafting specifically enumerated legislation; it decreases the risk that Congress will neglect to enumerate a state function it intended to affect; it results in flexible statutes that can be adapted to changing circumstances; and it minimizes the waste of legislative and judicial resources inherent in a congressional override of a statutory interpretation decision. 


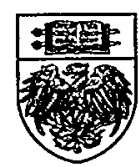

